\title{
Grundtvig-Studier 1959
}

udsendes i september r959 af det i r 947 stiftede Grundtvig-Selskab. Bogen indledes med en stor og meget interessant afhandling om »Grundtvig og de latinske salmer« af stud. mag. Jørgen Elbek, København. Seminarierektor, mag. art. Morten Bredsdorff, Vordingborg, belyser emnet »Sjællandske træk i Grundtvigs sprog og digtning «, medens bogens redaktør, professor, dr. phil. Gustav Albeck, Aarhus, i en afhandling om »Huslæreren paa Egeløkke« tager spørgsmaalet om Grundtvigs forelskelse i Constance Leth op til ny undersøgelse.! Bogen indeholder desuden mindre bidrag af cand. mag. Steen Johansen, København, pastor $K$. E. Bugge, København, samt domprovst, dr. theol. Henning Høirup, Viborg.

Herudover indeholder bogen engelske resumeer ved bl. a. dr. Noëlle Davies, Irland, samt en fortegnelse over Grundtvig-litteraturen i I957 ved cand. mag. Steen Johansen.

Tidligere udkom:

Grundtvig-Studier I 948. Gyldendal. I I 6 sider. Grundtvig-Studier 1949. Gyldendal. I I 2 sider. Grundtvig-Studier I 950. Gyldendal. I I 2 sider. Grundtvig-Studier I 95 I. Gyldendal. I 32 sider. Grundtvig-Studier 1952. Gyldendal. I 08 sider. Grundtvig-Studier I 953. Gyldendal. I 28 sider. Grundtvig-Studier I 954. Gyldendal. I 6 sider. Grundtvig-Studier I 955. Gyldendal. I 20 sider. Grundtvig-Studier 1956. Gyldendal. I 6 sider. Grundtvig-Studier 1957. Gyldendal. 132 sider. Grundtvig-Studier 1958. Gyldendal. I 24 sider.

I serien Skrifter udgivet af Grundtvig-Selskabet er hidtil udkommet:

I. Henning Høirup: Grundtvigs Syn paa Tro og Erkendelse. Gyldendal 1949. 420 sider.

II. Helge Toldberg: Grundtvigs symbolverden. Gyldendal i950. XII +356 sider.

III. Magnus Stevns: Fra Grundtvigs Salmevarksted. Udgivet af Henning Høirup og Steen Johansen. Gyldendal I950.

IV. Villiam Grønbak: Psykologiske tanker og teorier hos Grundtvig. Gyldendal I 95 I. I 92 sider.

V. Carl Weltzer: Grundtvig og Søren Kierkegaard. Gyldendal 1952. 96 sider.

VI. William Michelsen: Tilblivelsen af Grundtvigs historiesyn. Gyldendal I954. 368 sider.

VII. Henning Høirup: Fra døden til livet, Grundtvigs tanker og liv og død. Gyldendal 1954. I 12 sider.

VIII. Niels Kofoed: Grundtvig som selvbiograf. Gyldendal 1954. 136 sider.

IX. William Michelsen: Den salsomme forvandling i N. F. S. Grundtvigs liv. Gyldendal 1956. 288 sider.

X. N.F.S. Grundtvig: Taler paa Marielyst Højskole I 856-7 I, udgivet af Steen Johansen. Gyldendal I 956 . I 6 sider. 